\title{
RECENZJE
}

\section{Michalina Biernacka*}

Kreatywny trening percepcji przed artykulacją - czyli ćwiczenia fonetyczne uwzględniające prawidłową drogę akwizycji. Uwagi na marginesie książki Ewy Kołaczek, Testuj swój polski - Fonetyka (Prolog, Kraków 2017, ss. 166)

Słowa kluczowe: fonetyka, podręczniki do nauczania wymowy polskiej dla obcokrajowców, fonodydaktyka

Streszczenie. Celem recenzji jest omówienie publikacji Testuj swój polski - Fonetyka autorstwa Ewy Kołaczek, najnowszego zbioru ćwiczeń fonetycznych do nauczania języka polskiego jako obcego na poziomach biegłości A1-B1 w skali ESOKJ. Jakościowa analiza materiału, proponowanych typów ćwiczeń czy uporządkowania samych zagadnień pozwala uznać książkę za interesujący i dobry materiał do treningu zarówno słuchu mownego, jak i artykulacji.

Seria TESTUJ SWÓJ POLSKI, wydawana przez Wydawnictwo Prolog, z założenia ma być uzupełnieniem m.in. podręczników kursowych HURRA!!!, choć poszczególne publikacje mogą być wykorzystywane samodzielnie i wybiórczo. Najnowsza książka Ewy Kołaczek (2017), której tematem jest fonetyka języka polskiego, według informacji zamieszczonych na okładce ma służyć zarówno pracy indywidualnej, jak i grupowej od początku nauczania do poziomu B1. Składa się z 70 rozdziałów traktujących o rozmaitych zagadnieniach z segmentalnej i suprasegmentalnej płaszczyzny języka polskiego w odniesieniu do treningu percepcji oraz odpowiedniej artykulacji. Zwraca uwagę na zdecydowaną większość trudności, jakie cudzoziemcy mogą napotkać podczas uczenia się języka polskiego w zakresie płaszczyzny fonemowo-fonetycznej, co jest z pewnością dużym walorem publikacji. Na końcu zamieszczono angielskie thumaczenie wszystkich poleceń zawartych w podręczniku oraz rubrykę Warto wiedzieć, że.., charakterystyczną dla tej serii, która tłumaczy trudniejsze zagadnienia bądź też podaje ciekawostki związane z tematem. Całość dopełniają angielsko-niemiecki słowniczek oraz klucz do wielu ćwiczeń. Podobna publikacja nie mogłaby się obejść bez materiału dźwiękowego, wobec czego nagrania ćwiczeń dołączone zostały na płycie CD i trzeba przyznać, że ich jakość jest wyjątkowo dobra (zróżnicowane płciowo głosy lektorów, bardzo dobra wymowa i - co jednak rzadkie w podobnych publikacjach - niezwolnione, ale i niezbyt szybkie tempo, wielokrotnie w zadaniach zmieniane) - materiał opracowany został przez Studio Nagrań Nieustraszeni Łowcy Dźwięków. Na komentarz zasługuje także sama szata

*michalina.biernacka@uni.lodz.pl, Uniwersytet Łódzki, Wydział Filologiczny, Instytut Filologii Polskiej i Logopedii, Zakład Lingwistyki Stosowanej i Kulturowej, ul. Pomorska 171/173, 90-236 Łódź, ORCID: 0000-0002-2414-9745. 
graficzna omawianego zbioru ćwiczeń fonetycznych, wpisująca się w schemat całej serii, nienadmiernie kolorowa (nie odwraca uwagi uczących się), ale i bez narzucającej się rutyny w sposobie prezentowania treści ${ }^{1}$.

Bardzo ważną cechą publikacji jest to, że Autorka równie mocno jak na wymowie, koncentrowała się na ćwiczeniach słuchu mownego (Biernacka 2014), zwykle poprzedzających ćwiczenia artykulacyjne (odstępstwa zaobserwowano kilkukrotnie, lecz wyłącznie w sytuacji, gdy dane dźwięki mowy przećwiczone zostały w poprzednich rozdziałach). Taki układ materiału pozwala na elementarne (ze względu na małą liczbę ćwiczeń w każdym z rozdziałów), lecz jednak właściwe metodologicznie kształtowanie kompetencji fonologicznej uczących się (ESOKJ 2003). Wbrew niemu uporządkowany jest jednak spis treści, w którym każdorazowo najpierw wymieniona jest wymowa, a po niej różnicowanie głosek, co jednak poczytuje się jako zabieg stylistyczny zastosowania paralelnego układu względem pozostałych rozdziałów (np. „,wymowa i różnicowanie samogłosek ustnych" - spis treści, s. 3).

W celu kształtowania umiejętności rozpoznawania dźwięków mowy wykorzystano wiele standardowych technik, np. dopasowywanie wyrazu usłyszanego do napisanego (s. 11), uzupełnianie luk literowych lub sylabowych (s. 13, 19) czy odnajdywanie słów niepasujących do pozostałych / nieprzeczytanych (s.14). Warto w tym miejscu wspomnieć, że nie unikano technik wymagających włączenia dodatkowych procesów myślowych, np. liczenia w ćwiczeniach na dyskryminację (ze stron $22,26,41$ ) czy zapisywania pełnych słów (s. 43). Szczególnie cenne są tu wszystkie ćwiczenia dotyczące akcentu i intonacji, nie pominięto nawet percypowania różnic w intencjach nadawczych. Należy nadmienić, że nawet jeśli forma ćwiczenia się powtarzała, to graficzny sposób prezentacji ulegał zmianie (por. uzupełnianie liter na stronach 19 i 25). Co ważne, często dźwięk łączono z obrazem, zarówno pojedynczym elementem graficznym wizualizującym głoskę na zasadzie reprezentatywnego z nią wyrazu (por. s. 34), jak i komunikacyjnie w dialogach (s. 35). Rozdziały dotyczące rozróżniania głosek - a właściwie niesamogłosek (spółgłosek i glajdów) - to próba zdaniowa testu słuchu mownego, niekiedy dwu, a niekiedy trójelementowa, brakuje jednak wielu innych ważnych opozycji fonologicznych, by była pełna ${ }^{2}$.

$\mathrm{Na}$ uwagę zasługuje także różnorodność ćwiczeń artykulacyjnych proponowanych przez Autorkę, obejmujących podsystemy wokaliczny, konsonantyczny i prozodyczny polszczyzny. Wykorzystano nie tylko samo verbum, ale i bodźce wzrokowe w postaci obrazków, zdjęć czy ciekawych dialogów, wpisujących się dobrze w podejście komunikacyjne. Za podobnie wartościowe działanie uważa się wplatanie fragmentów wierszy, np. Jana Brzechwy czy też popularnych piosenek (Szła dzieweczka do laseczka). Synkretyzm technik nauczania przejawia się bardzo wyraźnie w wizualizacjach intencji nadawczych za pomocą swoistych emotikonów czy nawet próśb o dorysowywanie odpowiednich kształtów układu warg podczas artykulacji spółgłosek dentalizowanych. Do innych ciekawszych pomysłów warto zaliczyć wszystkie zadania komunikacyjne oparte na komiksach,

${ }^{1}$ Takie rozwiązanie wydaje się trafiać do większości cudzoziemców, choć m.in. uczący się z Dalekiego Wschodu wolą pewnego rodzaju powtarzalność, której tu uniknięto. Oczywiste jest jednak, że nie dałoby się dwu tak odrębnych koncepcji połączyć.

${ }^{2}$ Brak w publikacji informacji odautorskich tłumaczących pewne merytoryczne wybory, przypuszcza się więc, że dokonano ich arbitralnie na bazie doświadczeń metodycznych, np. brak ćwiczeń na różnicowanie par c:k, s:z, s:sz (są już w ciągach, m.in. s:si:sz - s. 41). 
wykorzystanie kaligramu w rozdziale Marzenie Marzeny lub też wprowadzanie elementów kulturowych (Jan Matejko, mapa Polski, Kraków). Warto zaznaczyć, że większość podręczników przeznaczonych do nauczania wymowy (Karczmarczuk 2012; Majewska-Tworek 2010; Madelska 2010) oraz podręczników kursowych na poziomy A i B (m.in. Stempek, Stelmach, Dawidek, Szymkiewicz 2011; Piotrowska-Rola, Porębska 2012) proponuje wyłącznie ćwiczenia koncentrujące się na polskich głoskach - zapominając niejako o prozodii. W ramach technik nauczania właściwej artykulacji skorzystano przede wszystkim z powtarzania za nagraniem (głosy obu płci), w zróżnicowanym tempie, niekiedy proszono też od odczyt przed odsłuchem (produkcja przed imitacją), mającym działać weryfikacyjnie (przy takim postępowaniu pojawia się większa liczba błędów). Imitacja obejmowała głoski (s. 34), sylaby (s 37), onomatopeje (s. 47), wyrazy (s. 50), połączenia wyrazowe (s. 40), zdania (s. 76), łamańce językowe (s. 54) czy wiersze (s. 58). Do mniej standardowych technik należy porównywanie wymowy własnej z nagraniem - niemniej warto dodać, że uczący się powinni swoją artykulację zarejestrować, by ten sposób pracy mógł przynieść efekty. Istotne są też indukcyjne ćwiczenia trenujące wymowę grup głoskowych wewnątrzwyrazowo i międzywyrazowo, w których obcokrajowcy proszeni są o samodzielnie spostrzeganie reguł rządzących upodabnianiem się grup niejednorodnych pod względem dźwięczności (s. 66).

Kłopoty, na jakie natrafić może lektor, chcąc pracować z omawianą publikacją, wynikają z niedookreślonego poziomu poszczególnych ćwiczeń. Zgodnie ze słowami zamieszczonymi na okładce książka kierowana jest do studentów rozpoczynających naukę i może ich w rozwijaniu kompetencji fonologicznej wspierać aż do poziomu B1. Ten dość szeroko zakrojony przedział biegłości nie jest rzadki w publikacjach fonodydaktycznych (z uwagi na wiele czynników warunkujących trudności w przyswajaniu wymowy obcego języka, takich choćby jak interferencje języka pierwszego), niestety nigdzie w książce nie odnajdujemy informacji pozwalających początkującym lektorom czy też samym cudzoziemców zorientować się, które ćwiczenia przeznaczone są na jaki poziom / dla kogo. Trudność ćwiczeń z pewnością nie wzrasta w sposób linearny, ponieważ już w pierwszym rozdziale - omawiającym internacjonalizmy - znajduje się ćwiczenie, w którym należy ocenić poprawność wymowy poszczególnych wyrazów osadzonych w wypowiedzeniach.

Układ treści przebiega od internacjonalizmów (zgodnie z zasadą poszukiwania elementów znanych uczącym się dla wzmocnienia motywacji), akcentu wyrazowego i zdaniowego (to pierwsza publikacja fonodydaktyczna słusznie rozpoczynająca od kształtowania prozodii), literowania ${ }^{3}$ poprzez poszczególne segmentalne elementy systemu, a więc samogłoski, półsamogłoski, spółgłoski, grupy spółgłoskowe i bardziej skomplikowane zagadnienia (takie jak homofony), aż do między innymi umiejętności rozpoznawania intencji i emocji nadawcy. Taki układ zgodny jest z zasadą stop-

${ }^{3}$ Pewne wątpliwości budzi przytaczanie nazw liter alfabetu i proponowanie literowania, skoro publikacja odnosi się do wymowy, a jej celem nie jest też korelacja podsystemu fonicznego z ortograficznym. Bardziej zasadne byłyby ćwiczenia głoskowania, których jednak w materiałach brakuje. Być może integrowanie nauki fonetyki z pozostałymi podsystemami było jednak celem Autorki, jednak nie zostało to w żaden sposób skomentowane. Widać fragmenty łączące wymowę z podsystemem leksykalnym (homofony), gramatycznym (liczebniki) czy też ortograficznym (palindromy), jednak wybór korelacji nie zawsze jest uzasadniony, brakuje zaś innych, ważniejszych zdaje się połączeń, np. szerszych odniesień do fleksji, wymowy czasownika być w czasie przyszłym itp. 
niowania trudności, jednak wewnętrznie w ten właściwy podział wkrada się chaos zróżnicowania poziomu komplikacji poszczególnych ćwiczeń, a także nierówno rozłożonego nacisku na ćwiczenie wybranych głosek. Ilustrację niejednakowego traktowania treści - zapewne dla uzyskania większego urozmaicenia typów ćwiczeń - mogą stanowić przykładowo: rozdział 18. przeznaczony do pracy nad różnicowaniem i wymową głosek [c/s] (4 ćwiczenia i opis artykulacji), rozdział 21. służący wyłącznie nauce wymowy [ś] (również 4 ćwiczenia i opis), a także rozdział 24., traktujący o wymowie [ź] i różnicowaniu [z/ź/ž] - łącznie 3 ćwiczenia i opis wymowy tylko głoski [ź]. Zastanawiające jest też rozpoczynanie ćwiczeń głosek z tzw. trzech szeregów od afrykat, które na zasadzie akwizycji do języka rodzimego powinny być wprowadzane na końcu (por. Madelska 2009). Być może jednak zamiarem Autorki było wyjście od dźwięków, które - choć trudniejsze do uzyskania ze względu na stopień otwarcia narządów mowy - silniej zaznaczają miejsce artykulacji, a więc styku artykulatorów - co rzeczywiście w pracy z cudzoziemcami jest często istotniejsze.

W większości ćwiczenia, które odnaleźć można w publikacji, są dość krótkie. Zazwyczaj - biorąc pod uwagę jak niewiele czasu mają lektorzy na kształtowanie kompetencji fonologicznej - jest to słuszne podejście (per analogiam nauczyciel może bowiem zadania rozwijać). Przy założeniu jednak, że mają one służyć pracy indywidualnej, liczba powtórzeń czy opis reguł bywa niewystarczający (patrz: akcent wyrazowy).

Zdecydowanie walorem publikacji są wszelkie logopedyczne odniesienia, takie jak rysunki układu warg przy artykulacji samogłosek bądź spółgłosek trzech szeregów, ćwiczenia oparte na paronimach, logatomach, rebusach czy wręcz opisy artykulacji jako instrukcje fonetyczne (sugerowana jest niekiedy praca z wykorzystaniem lusterek). Do niektórych można mieć niestety zastrzeżenia merytoryczne, por. opis wymowy głoski [i]: ,język mocno napiera na dolne zęby, a jego przednia

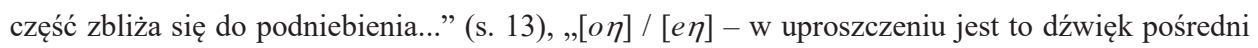
[on/ą] / [en/ę]” (s. 16), „w języku polskim głoski ą/ę należy wymawiać z pełną nosowością przed spółgłoskami: f, w, s, z, sz, ż/rz, ch...” (s. 15, 16) czy ,wymowa głoski l składa się z dwóch etapów: w pierwszej fazie czubek języka dotyka górnych dziąseł, a boczne krawędzie się obniżają. W drugiej fazie czubek języka odrywa się od dziąseł" (s. 22), uwagi o upodobnieniach w wyrazach typu trzeci, czwarty (s. 72) czy też wprowadzenie rozdziału o palindromach, który dotyczy ortografii, a nie fonetyki - szczególnie że wśród podanych przykładów znalazły się takie z geminatą (Anna) lub utratą dźwięczności w wygłosie (zaraz) - strona 71.

Dziwi brak rozróżnienia między głoską a literą, przyjmujący w publikacji rozmaite kształty, np. ,wymowa u/ó” (s. 14), ,na końcu słowa głoska ą zachowuje nosowośc”" (s. 15)5, mimo że w kilku miejscach pojawia się zapis w slawistycznym alfabecie fonetycznym (np. na stronie 16, wyjaśniający prawidłowe realizacje tzw. samogłosek nosowych), a nawet wymagany jest od uczących się zapis wymowy w ćwiczeniu na s. 67 (oczywiście uproszczony, dla oddania zmian dźwięczności, ale jednak w nawiasie kwadratowym). Tego rodzaju uproszczenia prowadzą do opisów komparatystycznych typu: „Głoska ź/zi jest spółgłoską dźwięczną (...). Powstały dźwięk jest zbliżony do głoski 's' w angielskim słowie 'pleasure', ale jest bardziej miękki” (s. 32), w których pojęcia głoski

${ }^{4}$ Warto postawić pytanie: jak Autorka rozumie termin „pełna nosowość”?

${ }^{5}$ Nie wydaje się, by było to słuszne uproszczenie terminologii, bowiem relacje głoska - litera obejmują wszystkie języki świata. 
i litery zdają się być utożsamiane. Przy okazji warto jednak wspomnieć, że wsparciem wyobrażeń słuchowych są właśnie liczne odniesienia do podobnych dźwięków mowy występujących w językach angielskim, niemieckim, włoskim czy francuskim - nie są one nowością (por. Miodunka 2001), bywają zaś mylącym uproszczeniem ${ }^{6}$.

Niektóre zadania, mimo że ciekawe strukturalnie, budzą wątpliwości teleologiczne, m.in. odnajdywanie ze słuchu niewypowiedzianego wyrazu spośród rodziny wyrazów (np. pustka, pustelnik, pustelnica, pustelnia, pustynia) jako ćwiczenie percepcyjne głoski [u] (s. 14), podkreślanie usłyszanego słowa spośród trzech możliwych z głoska [ś], gdy to odróżnienie jej od innych spółgłosek powinno być istotą, np. „Asia, Asi, Asiu!” (s. 29) czy też numerowanie w kolejności par homonimicznych (s. 70) - np. odróżnianie duetów [xart / xart] (ort. chart / hart), [lut / lut] (ort. lód / lud). Ciekawe ćwiczenie prezentuje rozdział 55, jednakże zapis w poleceniu, informujący o konieczności poszukiwania słów różniących się „od pozostałych pod względem jakości wymowy wyróżnianej głoski” jest dość nieprecyzyjny, szczególnie że ćwiczenie łączy wymowę spółgłosek dźwięcznych i bezdźwięcznych z realizacjami tzw. samogłosek nosowych w różnych kontekstach. Ponadto dodanie rozdziału o wymowie wyrażeń przyimkowych aż prosi się o ukazanie jedności brzmieniowej w obrębie grup spółgłoskowych w jakimś ćwiczeniu (która tylko wspomniana jest na s. 66).

Dobrą techniką - wbrew jednak zapisowi o jej wyjątkowości, bardzo popularną - są próby wymowy słów od końca z dodawaniem kolejnych sylab techniką backchaining [Komorowska 2005; Biernacka 2016]. Skoro jednak publikacja przeznaczona jest i dla niższych poziomów, warto choć na jednym przykładzie pokazać ją z wykorzystaniem słowa z poziomu początkowego, np. interesujacy. Ciekawa zaś jest wariacja techniki rozwinięcia z wykorzystaniem gry słownej, służącej - poprzez brzmieniowe asocjacje - ćwiczeniu najpierw krótszych form wyrazowych, aby przejść do trudnych liczebników (por. Gamon, Bragdon 2003). Niestety wydaje się, że wprowadzenie wymowy słowa cześć po to, by uczący się opanował realizację sześć (podczas gdy właśnie te dwa wyrazy stanowią jeden z częstszych problemów na poziomie początkowym ze względu na różnicę wyłącznie w stopniu zbliżenia narządów mowy) lub zięć dla opanowania wyrazu dziesięć (choć różnica dźwięczności często powoduje tu zamianę głosek na drodze interferencji) jest działaniem, które może naukę utrudnić (w obu sytuacjach nie uwzględniono cech dystynktywnych w trakcie kreowania zadania).

Cenne w zbiorze ćwiczeń jest to, że znalazły się w nim zadania na wyrażanie emocji (onomatopeicznie oraz przy pomocy intonacji), również na wyższe poziomy - z uwzględnieniem różnic w podziale granic wypowiedzeń. Interesujący jest rozdział odnoszący się do popularnych błędów wymowy i choć nie do końca jasne jest, dlaczego Autorka odróżnia kategorię wyrazów typu [prasować] jako pracować od wyrazów typu [kaos] jako chaos, [kały] jako cały (prawdopodobnie w pierwszej grupie wyrazów nacisk kładąc na konsekwencje zmian znaczeń wyrazów, a w drugiej grupie na próbę odzwierciedlania wymowy charakterystycznej dla języków pierwszych uczących się - co przecież może się na siebie nakładać - jak pokazuje ostatni z przykładów), to jednak bezpośrednie zwrócenie uwagi uczących się na jedne z najczęstszych pomyłek jest komunikacyjnie bardzo skutecznym sposobem motywowania do nauki.

${ }^{6}$ Choć Autorka stara się oceniać dźwięki mowy po względem barwy, komentując np. [ć] ,zbliżony jest do głoski 'ch' w angielskim słowie cheese , ale jest bardziej miękki”' (s 27). 
Nie udało się uniknąć problemów w konstruowaniu poleceń, choć są sporadyczne, np. mylące czy też wprowadzające w konsternację jest polecenie w rozdziale 22.: Proszę wystuchać nagrania i zakreślić słowa czytane przez lektora. Połaczone ze sobq ułatwia przejście przez labirynt i zaprowadza do wyjścia (s. 30) - można mieć więc wrażenie, że należy je jakoś słowotwórczo ze sobą związać. Można mieć też wątpliwości odnośnie do poziomu tekstu o Błoniach ze str. 82, szczególnie że nie ma jego tłumaczenia - podobnie jak i pozostałych tekstów czy treści ćwiczeń. Kilka istotnych ćwiczeń pozbawionych jest nagrań, np. rozdział 61. dotyczący wymowy liczebników złożonych, choć ćwiczenie w nim polega na odczytaniu liczby osób, które polubiły wybrane profile na Facebooku, np. 1625 908, to bez dźwiękowego wsparcia do porównania wymowy zadanie to nie nadaje się do samodzielnej pracy.

Podsumowując, warto podkreślić, że recenzowana publikacja łączy ze sobą cztery najistotniejsze metody nauczania wymowy języków obcych, a więc: artykulacyjną (objaśnianie sposobów artykulacji, uwzględniające nawet ryciny), audytywną (imitacja wymowy wzorcowej), kontrastywną (porównywanie głosek polskich do podobnych w innych językach europejskich, szczególnie angielskiego jako lingua franca) i werbo-tonalną (kładącą nacisk na prozodię). Całość okraszona jest pracą na parach minimalnych i z odniesieniem do różnorodnych asocjacji, wykorzystuje bodźce wzrokowe, słuchowe i werbalne, elementy tekstów kultury, a nawet dowcip, podszyta jest zaś ukierunkowaniem na komunikację.

Warto podkreślić, że omawiana publikacja w rękach doświadczonych lektorów jest z pewnością bardzo dobrym narzędziem, które pozwala ćwiczyć polską wymowę w sposób kreatywny i zróżnicowany. Brak informacji poziomujących zagadnienia lub/i poszczególne ćwiczenia - charakterystyczny zresztą dla całej serii - wzbudza jednak wątpliwości. Zastanawiający jest też brak wstępu odautorskiego, z którego czytelnik mógłby się dowiedzieć, jakie założenia metodologiczne i cele przyświecały pisaniu książki. Jako zbiór ćwiczeń fonetycznych do wykorzystania wedle uznania lektorów jest jednak zdecydowanie godną polecenia publikacją.

\section{BIBLIOGRAFIA}

Biernacka M., 2014, Stuch fonematyczny, fonetyczny czy mowny - rozważania terminologiczne, w: M. Gaze, K. Kubacka (red.), Bogactwo językowe i kulturowe Europy w oczach Polaków i cudzoziemców - 2, Łódź, s. 31-37.

Biernacka M., 2016, Znajdź z polskim wspólny język. Fonetyka w nauczaniu języka polskiego jako obcego, Łódź.

Europejski system opisu kształcenia językowego: uczenie się, nauczanie, ocenianie, 2003, thum. W . Martyniuk, Warszawa.

Gamon D., Bragdon A. D., 2003, Ucz się szybciej, zapamiętuj więcej, Warszawa.

Karczmarczuk B., 2012, Wymowa polska z ćwiczeniami, Lublin.

Kołaczek E., 2017, TESTUJ SWÓJ POLSKI - FONETYKA, Kraków.

Komorowska H., 2005, Metodyka nauczania języków obcych, Warszawa.

Madelska L., 2009, Język polski na tle języków świata a nauczanie wymowy w glottodydaktyce, „Poradnik Językowy”, z. 6, s. 38-55.

Madelska L., 2010, Posłuchaj, jak mówię (Podręcznik ucznia; Poradnik dla rodziców i nauczycieli; Film dydaktyczny). Materiaty do ćwiczenia stuchu i wymowy dla dzieci oraz dla dorostych, uczących się języka polskiego jako obcego, Wiedeń. 
Majewska-Tworek A., 2010, Szura, szumi i szeleści. Ćwiczenia fonetyczne nie tylko dla cudzoziemców, Wrocław.

Miodunka W., 2001, Cześć, jak się masz? A Polish Language Textbook for Beginners, Kraków.

Piotrowska-Rola M., Porębska M., 2012, Polski jest cool. Seria do nauki języka polskiego jako obcego na poziomie A1, Lublin.

Stempek I., Stelmach A., Dawidek S., Szymkiewicz A., 2011, Polski, krok po kroku. Poziom A1, Kraków.

Michalina Biernacka

\section{CREATIVE PRACTICE IN AUDITORY PERCEPTION PRECEEDING ARTICULATION - HOW THE CORRECT ACQUISITION CAN BE REFLECTED IN PHONETIC EXERCISES. REMARKS ON THE BOOK TESTUJ SWÓJ POLSKI - FONETYKA BY EWA KOLACZEK (PROLOG PUBLISHING COMPANY, KRAKÓW 2017, PP. 166)}

Keywords: phonetics, Polish pronunciation textboos for foreigners, phonodidactics

Summary. The aim of the article is to review the textbook Testuj swój polski-Fonetyka by Ewa Kołaczek. It is the newest collection of phonetic exercises for Polish as a foreign language at the A1-B1 levels (according to CEFR). The qualitative analysis of the material, the proposed types of exercises and the arrangement of phonetic issues allow for the conclusion that the textbook is an interesting teaching aid which can help develop the phonological and phonetic competencies. 